\title{
DIGITALISASI PEMASARAN KERIPIK TEMPE DALAM MENGHADAPI PERSAINGAN DAGANG SELAMA PANDEMI COVID-19
}

\author{
Muhammad Syahril Imron ${ }^{1}$, Yudha Nurdian ${ }^{1}$ \\ ${ }^{1}$ Universitas Jember, Jember, Indonesia \\ syahrilimron54@gmail.com
}

\begin{abstract}
Abstrak: Indonesia saat ini mengalami kondisi krisis atau bencana yang disebabkan oleh Coronavirus Disease 2019 (Covid-19) yang menyebar luas hingga ke daerah Jember. Berbagai kebijakan untuk mencegah penyebaran covid-19 justru berimplikasi buruk terhadap beberapa sektor lain khususnya pada sektor ekonomi. Dampak ini jelas juga dirasakan oleh pelaku usaha keripik tempe yang berada di kelurahan Sumbersari, seperti tingkat penjualan menurun dan metode pemasaran yang masih terbatas secara langsung (luring). Adanya program Kuliah Kerja Nyata Back to Village (KKN-BTV) Universitas Jember bertujuan untuk mendampingi pelaku usaha "TEMPE GO" di kelurahan Sumbersari. Lebih spesifik, tujuan dari adanya kegiatan ini adalah memberikan edukasi dan pelatihan tentang proses produksi yang baik dan benar, pemasaran suatu produk secara digital, dan pembuatan beberapa platform digital. Metode yang digunakan pada kegiatan KKN BTV ini adalah Participatory Rural Appraisal (PRS) yang memungkinkan keterlibatan masyarakat dalam melaksanakan berbagai kegiatan, mulai dari observasi, pemberian sosialisasi tentang protokol kesehatan, sanitasi kerja dan proses produksi, pendampingan proses produksi, pendampingan pembuatan desain logo dan kemasan, pembuatan akun media sosial hingga promosi dan pemasaran produk. Upaya yang telah dilakukan untuk mewujudkan digitalisasi pemasaran "TEMPE GO" terwujud dengan terbentuknya akun instagram, whatsapp, tokopedia dan shopee sebagai media pemasaran digital. Masyarakat didorong untuk terus mengelola secara baik capaian kegiatan yang telah dilakukan demi terciptanya usaha yang berkelanjutan.
\end{abstract}

Kata Kunci: Covid-19, keripik tempe, pemasaran, digital

\begin{abstract}
Indonesia is currently experiencing a crisis caused by Covid-19 which has spread widely to Jember area, especially Sumbersari village. Various policies as an effort to prevent the spread have had bad implications for several other sectors, particularly in the economic sector. This impact is also clearly felt by people who have tempe chip business in Sumbersari village, such as declining sales levels and limited direct marketing methods (offline). The existence of the Back to Village Community Service Program at the University of Jember aims to assist "TEMPE GO" entrepreneurs in Sumbersari Village. More specifically, the purpose of this activity is to provide education and training on proper and correct production processes, digital marketing of a product, and the creation of several digital platforms. The method used in the program is Participatory Rural Appraisal (PRS), which allows community involvement in carrying out various activities, starting from observation, providing outreach on health protocols, work sanitation and production processes, production process mentorship, assistance in making logo and packaging designs, creating social media accounts to product promotion and marketing. The efforts made to realize the digitalization of Tempe Go marketing are the creation of Instagram, WhatsApp, Tokopedia and Shopee accounts as digital marketing media. The local people is encouraged to properly manage the achievements of the program in order to create a sustainable business.
\end{abstract}

Keywords: Covid-19, tempe chips, marketing, digital

\section{Pendahuluan}

Indonesia saat ini mengalami kondisi krisis atau bencana yang disebabkan oleh persebaran Coronavirus Disease 2019 (Covid-19). Berdasarkan data Gugus Tugas Percepatan Penanganan Covid-19, hingga Maret 2021 tercatat persebaran covid-19 di Indonesia mencapai 145.628 positif, 1.203 .381 sembuh dan 37.547 meninggal. Krisis pandemi ini menyebabkan 
perubahan di berbagai sektor kehidupan masyarakat. Berbagai kebijakan dikeluarkan pemerintah untuk memutus rantai persebaran virus ini, seperti kebijakan PSBB (Pembatasan Sosial Berskala Besar) di beberapa daerah, melakukan pekerjaan dari rumah (working from home), menjaga jarak fisik (physical distancing) dan kebijakan new normal saat ini. Hal ini berdampak terhadap pola kehidupan masyarakat, khususnya transformasi ke berbagai bentuk kegiatan yang sifatnya online ataupun daring.

Berdasarkan hasil penelitian dari Aminy \& Kartika (2020), pandemi covid-19 telah memberikan dampak negatif bagi UMKM Jawa Timur, yaitu $48 \%$ mengalami penurunan penjualan, 27,21\% mengalami kesulitan bahan baku, 9,88\% mengalami permasalahan permodalan, 7,72\% mengalami hambatan produksi. Salah satu daerah dari provinsi Jawa Timur yang terdampak yaitu Kelurahan Sumbersari, Kabupaten Jember. Letak kelurahan sumbersari tidak jauh dari pusat kota dan berada diantara Universitas Muhammadiyah Jember serta tidak jauh dari Universitas Jember-Tegal Boto. Hal ini menyebabkan masyarakat ataupun penduduknya lebih banyak bermata pencaharian sebagai pebisnis, baik itu seperti membuka kedai makanan, membuka kos atau rumah kontrakan hingga bisnis konveksi ataupun lainnya. Adanya pandemi ini jelas memberikan dampak kepada pelaku usaha di Jember, yaitu berbagai barang ataupun orang luar sulit untuk masuk dan begitupun tidak mengirim barang keluar wilayah sehingga harga kedelai impor naik hingga 5,5\%. Hal ini memberikan dampak kepada pelaku usaha olahan tempe, yaitu salah satunya pengusaha keripik tempe. Usaha ini baru berdiri pada 16 Juni 2020 yang berlokasi di jalan kalimantan X kelurahan Sumbersari, kecamatan sumbersari, kabupaten Jember Jawa Timur. Usaha kerpik tempe ini masih tergolong baru, sehingga memerlukan berbagai inovasi untuk memperluas pasar penjualannya agar dapat bertahan di tengah-tengah pandemi.

Berbagai kebijakan yang muncul sebagai upaya mencegah persebaran covid-19 justru berimplikasi buruk terhadap beberapa sektor lain, khususnya pada sektor ekonomi. Hal terlihat pada berkurangnya omset atau keuntungan dari pengusaha di sektor makanan. Menurut laporan dari Organisation for Economic Co-operation and Development (OECD), adanya pandemi akan memicu terjadinya krisis ekonomi yang besar, hal ini ditandai dengan aktivitas produksi terhenti, tingkat konsumsi masyarakat menurun, kepercayaan konsumen menghilang dan bursa saham jatuh. Berdasarkan data dari Kementerian Koperasi dan Usaha Kecil Menengah (KemenkopUKM) terdapat 64.194.057 UMKM yang terdaftar atau sekitar 99\% dari total usaha dan menyumbang 116.978.631 tenaga kerja di Indonesia. Hal ini menjadikan UMKM sebagai tulang punggung perekonomian nasional, namun dengan adanya kondisi saat ini terdampak secara serius (Pakpahan, 2020). Dampak ini jelas juga dirasakan oleh pelaku usaha keripik tempe yang berada di kelurahan Sumbersari, seperti tingkat penjualan menurun dan metode pemasaran masih terbatas secara langsung (luring). Oleh karena itu, perlu adanya inovasi pemasaran dalam rangka meningkatkan daya jual dan memperluas pasar produk.

Pemasaran menjadi salah satu hal yang sangat penting dalam kegiatan berwirausaha, baik usaha dalam skala kecil ataupun usaha dalam skala besar. Menurut Kottler \& Keller (2009), pemasaran yaitu kegiatan dalam memberikan kepuasan kepada pelanggan terhadap apa yang dibutuhkan. berdasarkan prakteknya, pemasaran yaitu proses mengelola atau mengatur 
hubungan dengan pelanggan yang menguntungkan. Adapun lima konsep yang perlu dipahami dalam mewujudkan strategi pemasaran yaitu konsep produksi, konsep produk, konsep penjualan, konsep pemasaran dan konsep berwawasan sosial. Ketika dihubungkan dengan zaman sekarang atau biasa disebut dengan era revolusi industri 4.0, yaitu teknologi menjadi proyeksi untuk menguasai seluruh sektor kehidupan manusia, termasuk di dalamnya pada sektor usaha. Hal ini ditambah dengan adanya kondisi pandemi yang mengharuskan manusia tetap berada di rumah masing-masing sehingga penggunaan teknologi berbasis digital semakin meningkat. Di sisi lain ini menjadi sebuah peluang bagi pelaku usaha dalam memanfaatkan media pemasaran di era digital. Pemasaran yang dilakukan dengan memanfaatkan platformplatform digital atau marketplace membuat konsumen dapat menikmati produk tersebut dengan tetap berada di dalam rumah masing-masing (Kusumawardhani, Ignatius, Alfiatul \& Agus, 2020).

Pemanfaatan media-media sosial sebagai wadah untuk pemasaran secara digital masing belum diterapkan secara maksimal, terkhusus bagi masyarakat atau pelaku usaha yang mempunyai latar belakang pendidikan yang rendah ataupun termasuk dalam generasi tua yang gagap teknologi. Hal ini juga akan dipengaruhi dengan strategi ataupun inovasi yang digunakan sebagai upaya keluar dari tantangan pandemi covid-19 (Ibrahim \& Nurdian, 2020; Prayogo \& Nurdian, 2020; Purnamasari \& Nurdian, 2020; Wahyuni \& Nurdian, 2020). Pelaku usaha keripik tempe di kelurahan Sumbersari tergolong masih kecil, karena masih tergolong usaha baru dan pasarnya yang masih sempit. Oleh karena itu, program Kuliah Kerja Nyata Back to Village yang selanjutnya disebut dengan KKN-BTV Universitas Jember bertujuan untuk mendampingi pelaku usaha agar tetap bertahan di tengah krisis pandemi covid-19 dengan metode digitalisasi pemasaran. Lebih spesifik, tujuan dari adanya kegiatan ini yaitu memberikan edukasi dan pelatihan tentang proses produksi yang baik dan benar; pemasaran suatu produk secara digital; hingga pembuatan beberapa platform digital seperti instagram, whatssapp, tokopedia dan shopee.

\section{Metode}

Kegiatan ini dilakukan oleh Muhammad Syahril Imron mahasiswa jurusan Teknologi Hasil Pertanian, Fakultas Teknologi Pertanian, Universitas Jember. Bentuk kegiatan yang dilakukan berupa Kuliah Kerja Nyata (KKN) sebagai wujud pengabdian masyarakat seorang mahasiswa. Sasaran utama kegiatan pengabdian masyarakat ini dilakukan pada pelaku usaha keripik Tempe "TEMPE GO" di kelurahan Sumbersari milik Havid dan Yunus yang baru mempunyai pekerja tetap sebanyak 2 orang. Adapun metode yang digunakan pada kegiatan (KKN-BTV) ini yaitu Participatory Rural Appraisal(PRS), yaitu metode yang memungkinkan keterlibatan masyarakat dalam mengembangkan dan menganalisa pengetahuan mereka mengenai hidup dan kondisi mereka sendiri untuk perencanaan dan aksi (Emiliasari \& Kosmajadi, 2020). Maksud dari metode ini yaitu keterlibatan sasaran dalam mewujudkan berbagai program yang direncanakan menjadi hal yang sangat diperhatikan, sehingga ada hubungan timbal balik antar mahasiswa KKN-BTV dengan sasaran. Melalui metode ini, pelaku usaha keripik tempe bukan lagi objek yang 
menerima program, namun juga turut andil dalam program-program yang direncanakan dan bersama-sama mengidentifikasi alternatif-alternatif pemasaran yang mungkin dapat dijalankan sehingga dapat menentukan jalur pemasaran mana yang akan dipilih guna mempertahankan

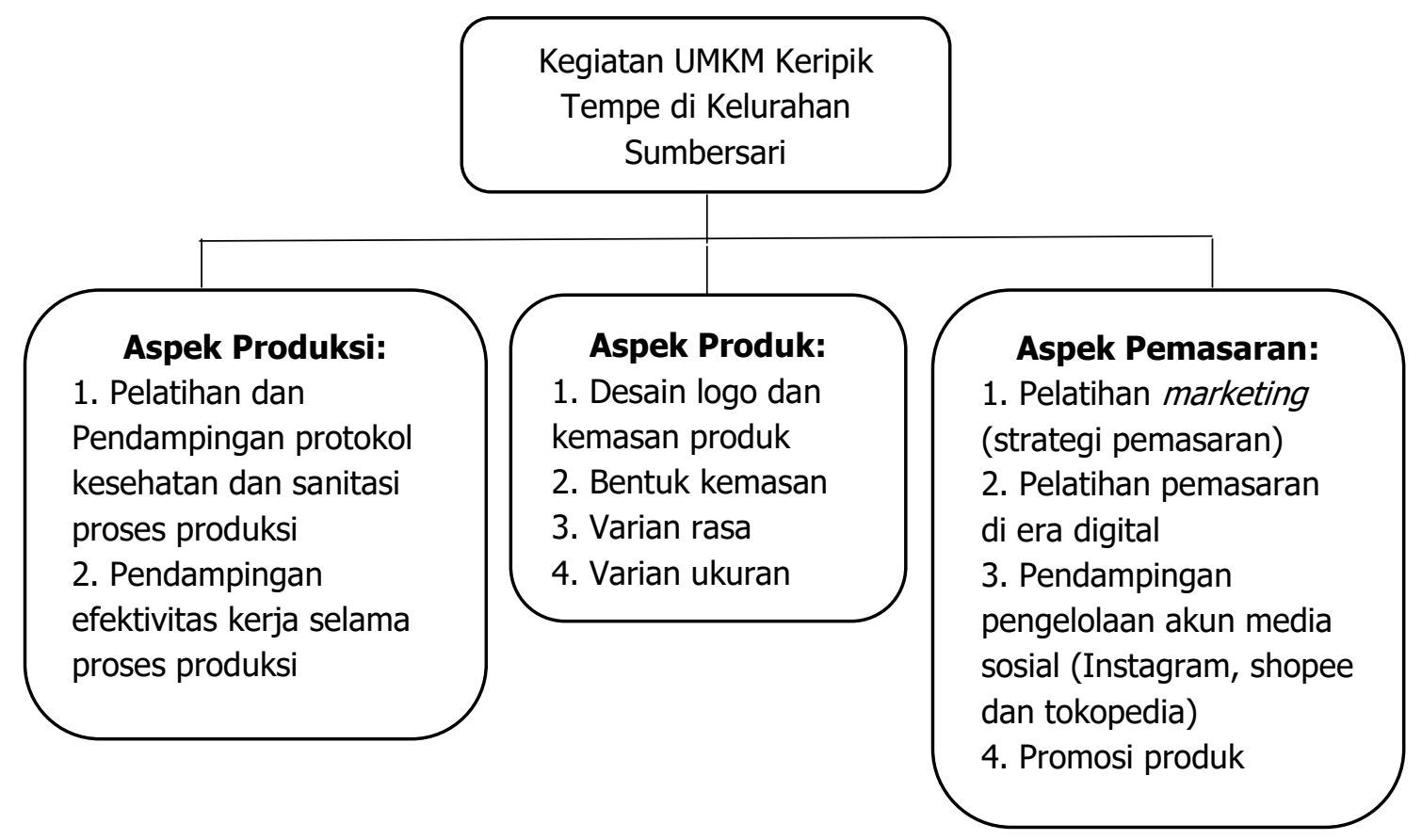

usaha di masa pandemi.

Bagan 1. Kerangka Kegiatan KKN-BTV

Kegiatan KKN-BTV dilakukan selama 45 hari, terhitung mulai tanggal 26 Januari sampai 11 Maret 2021 di Kelurahan Sumbersari, Kecamatan Sumbersari, Kabupaten Jember, Jawa Timur dengan sasaran utama pengusaha keripik tempe di jalan kalimantan $X$ Sumbersari Jember. Adapun beberapa tahapan kegiatan KKN-BTV II dalam upaya pendampingan penerapan digitalisasi pemasaran produk kerpik tempe di kelurahan Sumbersari yaitu sebagai berikut:

1. Minggu pertama, yaitu melakukan observasi terhadap usaha sasaran, di mana mengumpulkan hasil wawancara terkait kendala ataupun permasalahan yang dihadapi oleh pelaku usaha dan target saran ke depannya. Kondisi inilah yang nantinya menjadi bahan kajian untuk dirumuskan menjadi beberapa program kegiatan selama melaksanakan program KKN-BTV.

2. Minggu kedua, yaitu melakukan pengarahan terkait program kegiatan KKN-BTV yang akan dilaksanakan dan memberikan edukasi tentang produk keripik tempe, mulai dari pasar yang tersedia hingga beberapa pesaing lain yang juga bergerak pada usaha keripik tempe.

3. Minggu ketiga, yaitu melakukan pendampingan terkait proses pengolahan keripik tempe yang baik dan benar. Hal ini dimulai dari menerapkan protokol kesehatan dengan sempurna, sanitasi kerja hingga sanitasi proses produksi. 
4. Minggu keempat, yaitu melakukan pelatihan dan pendampingan terkait cara ataupun metode pengemasan, branding produk dan desain logo yang menarik. Hal ini bertujuan untuk meningkatkan ketertarikan konsumen untuk membeli produk.

5. Minggu kelima, yaitu melakukan pengenalan dan pembuatan akun media sosial sebagai wadah pemasaran secara digital, melalui akun whatsapp, instagram, shopee dan bukalapak. Kegiatan ini juga dalam rangka melakukan promosi dan memperkenalkan produk ini secara luas.

6. Minggu keenam, yaitu melakukan evaluasi terkait sistem pemasaran dan respon konsumen terhadap produk keripik tempe yang dipasarkan.

7. Minggu ketujuh, yaitu melakukan penyusunan laporan hasil kegiatan KKN-BTV.

\section{Hasil dan Pembahasan}

Keripik tempe merupakan produk makanan ringan yang terbuat dari olahan tempe. Menurut Nugraha (2011), keripik merupakan makan ringan yang bersifat kering dan renyah. Renyah yang dimaksud yaitu mempunyai tekstur yang keras dan mudah patah. Sifat renyah, tahan lama, praktis, mudah dibawa dan disimpan merupakan kelebihan yang dimiliki oleh keripik. Keripik Tempe menjadi salah produk makanan ringan hasil olahan tempe dengan kadar protein yang cukup tinggi yaitu berkisar antara 23\%-25\%. Hal ini dikarenakan adanya sumber protein dari kedelai yang berperan sebagai bahan dasar pembuatan tempe. Tempe memiliki kandungan gizi yang tinggi, khususnya yaitu kandungan proteinnya. Protein dalam tempe dapat dikatakan sebanding dengan protein dalam daging. Setiap 100 gram tempe terdapat protein sebesar 18,3 gram yang sebanding dalam setiap 100 gram daging ayam yaitu sebesar 18,2 gram. Tempe juga memiliki kandungan asam amino esensial yang cukup lengkap, yaitu seperti isoleusin, leusin, lisin, metionin, fenilalanin, dll. Asam amino esensial ini tidak dapat disintesis oleh tubuh dan dapat memberikan banyak manfaat bagi tubuh (Sarwono, 2008).

Usaha keripik tempe di kelurahan Sumbersari pada awalnya berdiri pada tanggal 16 Juni 2020. Awal mulanya merintis usaha ini yaitu dilatar belakangi dengan kondisi ekonomi yang serba susah di masa pandemi. Kondisi pandemi yang terjadi di awal bulan Maret 2020 memberikan dampak yang sangat terasa terhadap ekonomi keluarga. Hal ini juga berdampak di tetangga-tetangga sekitar. Berdirinya usaha keripik tempe disamping bertujuan untuk meningkatkan perekonomian keluarga secara mandiri juga dapat memberdayakan beberapa warga sekitar yang berhenti bekerja karena adanya pandemi. Usaha keripik tempe di kelurahan Sumbersari setiap minggunya melakukan produksi sebanyak tiga kali pembuatan tempe (terpotong waktu fermentasi) dan tiga kali penggorengan. Setiap produksi memerlukan bahan $4 \mathrm{~kg}$ tempe dan $2,5 \mathrm{~kg}$ taipoka sehingga dapat menghasilkan keripik tempe sebanyak $4 \mathrm{~kg}$ keripik siap makan. Adapun brand nama yang digunakan oleh pengusaha ini yaitu "TEMPE GO". Brand nama ini sebagai wujud harapan usaha ini akan senantiasa berjalan layaknya makna dari kata "GO" yaitu pergi. Harapannya keripik tempe ini dapat dipasarkan hingga berbagai daerah, atau bahkan dapat menembus pasar internsional. Namun, produk keripik tempe brand Tempe Go masih tergolong kecil dan memiliki pasar yang relatif sempit, karena masih dalam lingkup 
area Jember. Keripik tempe ini dijual dengan varian rasa, yaitu rasa pedas dan original. Keripik tempe ini juga dikemas dengan berbagai ukuran, mulai dari pengemasan dengan ukuran 80 gram dalam wadah standing pouch dengan harga Rp10.000, ukuran 250 gram dalam wadah plastik dengan harga Rp15.000 dan ukuran 500 gram dalam wadah plastik dengan harga Rp27.000.

\section{Implementasi KKN-BTV}

Kegiatan KKN-BTV yang dilakukan selama 45 hari di UMKM keripik tempe dapat memberikan gambaran terkait berbagai kendala yang dihadapi oleh usaha ini. Hal mendasar yang menjadi kendala dan pada umumnya juga dialami oleh UMKM lain khususnya di masa pandemi yaitu tekait naik turunnya jumlah pemasaran produk. UMKM ini masih terglong baru, sehingga memerlukan berbagai kegiatan ataupun perbaikan-perbaikan terkait sistem yang digunakan. Hal ini menjadi sebuah upaya yang dilakukan oleh M. Syahril Imron salah satu mahasiswa program KKN-BTV dalam membantu pendampingan jalannya usaha keripik tempe, khususnya dalam pemasaran di era digital.

Berbagai kegiatan dilakukan untuk menunjang kebutuhan UMKM keripik tempe agar tetap dapat bersaing dengan pesaing-pesaing lain. Kegiatan-kegiatan ini dirancang dalam sebuah program KKN-BTV yang dimanifestasikan pada setiap minggunya. Langkah awal yang dilakukan yaitu mendeteksi berbagai masalah ataupun kendala yang dialami. Tercatat bahwa UMKM ini masih belum memanfaatkan media sosial secara maksimal untuk melakukan pemasaran dan promosi. Hal inilah yang menjadi modal awal mahasiswa KKN-BTV untuk membantu dan meningkatkannya. Pemaksimalan minggu pertama terkait observasi berbagai masalah dan peluang yang dapat dikembangkan. Adapun rencana-rencana awal telah dibuat dengan mulai meghidupkan beberapa media sosial dan media promosi untuk menunjang pemasaran. Menurut Kurniawan (2017), media sosial kini terus merambah dalam setiap lini kehiduapan manusia sehingga dapat dimanfaatkan sebagai sarana promosi dan pemasaran produk dan jasa tertentu. Banyak jenis media sosial yang dapat diakses, seperti facebook, instagram, whatsapp, youtube dan twitter bahkan beberapa marketplace seperti shopee, bukalapak, lazada dan tokopedia.

Kegiatan yang dilakukan selama KKN-BTV dimulai dari pemberian edukasi terkait pasar dan pesaing usaha keripik tempe lainnya. Keripik tempe sendiri bukan merupakan produk baru, sehingga terdapat banyak kompetitor lain yang bergerak pada usaha keripik tempe. Hal ini tentu tidak justru menghilangkan semangat untuk berwirausaha, namun dapat memicu munculnya semangat untuk senantiasa berinovasi sehingga produk tempe yang dihasilkan mempunyai kecirian khusus atau keunikan. Pasar penjualan yang semakin luas juga menjadi sebuah pandangan bahwa, berbisnis bukan berarti hanya terletak di satu daerah saja, namun dapat menembus daerah-daerah lain dengan bantuan teknologi. Adanya KKN BTV membantu pelaku usaha untuk memunculkan inovasi-inovasi baru, seperti pembaharuan metode pemasaran yang dilakukan, peningkatan kebersihan saat proses produksi hingga memperbaharui beberapa konten, logo ataupun kemasan produk. 


\section{Proses Produksi}

Kegiatan KKN-BTV ini dilanjutkan dengan memberikan edukasi terkait penerapan protokol kesehatan hingga sanitasi kerja dan proses produksi. Edukasi ini tidak hanya dilakukan dengan sosialisasi saja. Namun, juga diterapkan selama pendampingan KKN-BTV, sehingga selama kegiatan ini berlangsung, seluruh pekerja menerapkannya dengan baik dan benar. Harapannya produk yang dihasilkan mempunyai tingkat keamanan yang tinggi untuk dikonsumsi. Kegiatan ini dilakukan dengan mengikuti seluruh proses produksi keripik tempe dari awal hingga akhir. Adapun proses produksi keripik tempe yang diterapkan di UMKM Tempe Go yang pertama yaitu menyiapkan tempe yang belum jadi (tempe yang masih berupa kedelai dan sudah ditambah ragi di dalamnya). Langkah selanjutnya yaitu dilakukan pencampuran dengan tepung tapioka, adapun formulasi yang digunakan yaitu tempe (kedelai) sebanyak $4 \mathrm{~kg}$, tepung tapioka sebanyak $2,5 \mathrm{~kg}$ dan dicampur hingga merata. Setelah itu, tempe dimasukkan wadah plastik yang berbentuk silinder (diisi hingga padat) dan digantung dalam suhu ruang untuk melakukan proses fermentasi selama 2 hari. Tempe yang telah terfermentasi selama 2 hari kemudian diiris tipis-tipis menggunakan alat pemotong dan dilakukan penggorengan hingga pengemasan. Gambaran proses produksi kripik tempe ini sebagaimana pada Gambar 1.

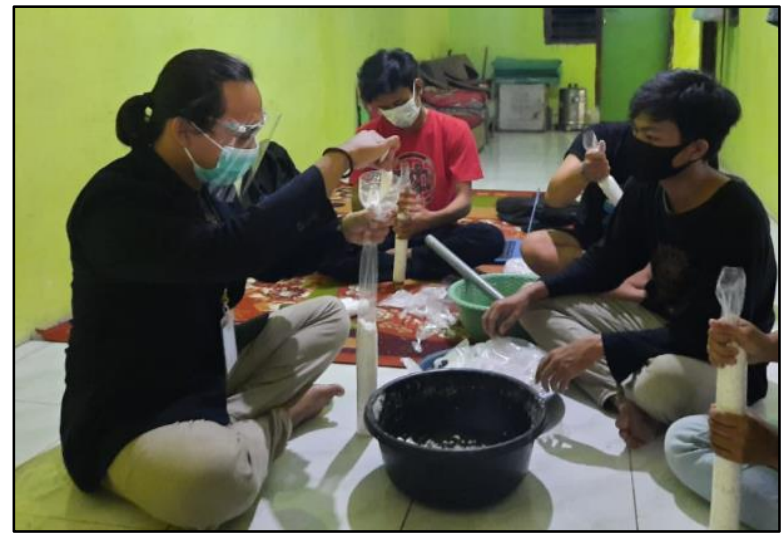

Gambar 1. Proses Produksi Keripik Tempe

\section{Produk "TEMPE GO"}

Gambar 2 merupakan beberapa hasil desain kemasan selama KKN BTV berlangsung, mulai dari kemasan lama hingga kemasan terbaru. Menurut Boyd (2000), kemasan merupakan hal yang pertama yang akan dilihat oleh konsumen, sehingga dapat mempengaruhi tingkat penerimaan dan mampu mengubah persepsi konsumen dalam mengambil keputusan apakah membeli atau tidak akan melanjutkan proses pembelian. Hal ini menjadi dasar adanya kegiatan pelatihan dan pendampingan pembuatan desain logo ataupun kemasan yang menarik, sehingga dapat meningkatkan ketertarikan konsumen pada produk Tempe Go. Adanya desain kemasan yang menarik menjadi langkah awal dalam melakukan branding produk, khususnya pada produk keripik tempe sehingga dapat bersaing dengan usaha-usaha sejenis lainnya. Adapaun desain kemasan yang digunakan produk Tempe Go mengalami perubahan, terutama saat kegiatan KKN ini berlangsung. Hal ini bertujuan untuk memperbaiki desain kemasan yang telah ada sehingga menjadi lebih baik lagi. 

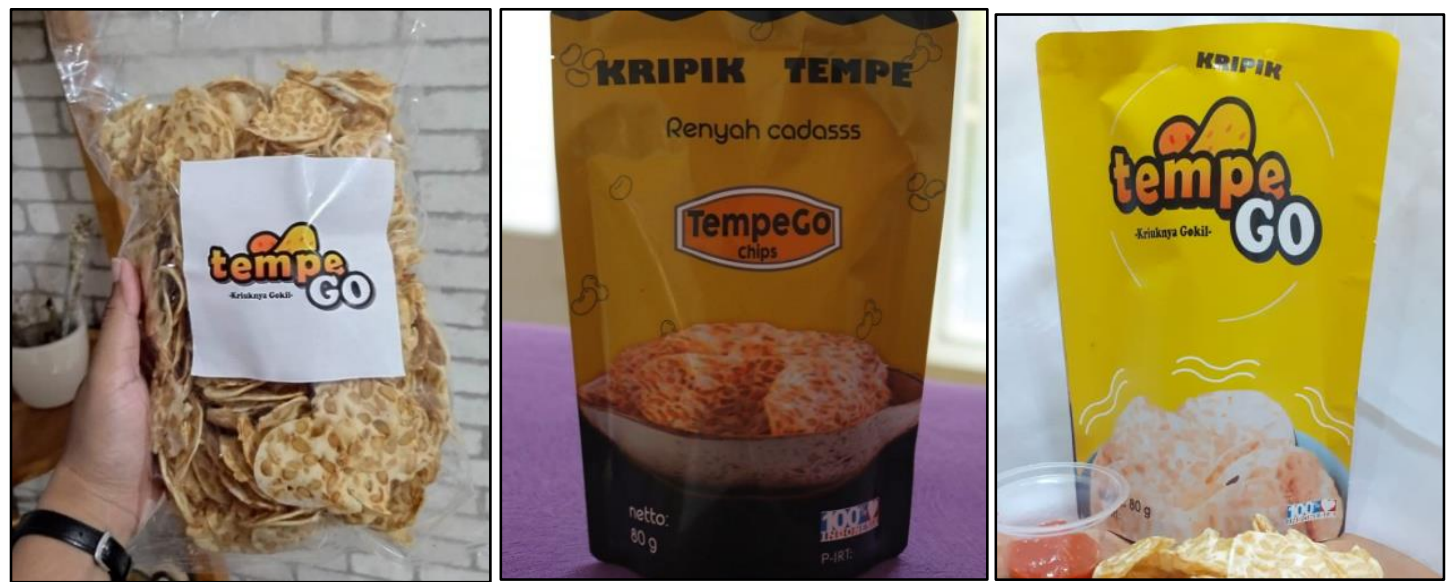

Gambar 2. Desain Kemasan ke 1, 2 \& 3

\section{Pemasaran Produk Secara Digital}

Penggunaan internet ataupun media sosial sebagai tempat transaksi bisnis sudah dianggap sebagai suatu hal yang penting dan biasa di kalangan masyarakat. Hal ini ditandai dengan meningkatnya jumlah pengusaha yang menggunakan e-commerce dalam perusahaannya. Menurut Aryansah, Mirani \& Martina (2020), media sosial dapat dimanfaatkan ke berbagai kepentingan, mulai dari menjalin pertemanan, kampanye program-program tertentu hingga promosi dan pemasaran produk. Terdapat beberapa jenis platform digital yang dapat digunakan untuk menyediakan jasa jual-beli secara online, diantaranya yaitu Bukalapak, Tokopedia, Shopee, Lazada. Keempat layanan e-commerce ini melonjak di masa pandemi. Pendampingan yang dilakukan mahasiswa selama KKN BTV memberikan sebuah pelatihan dalam pembuatan dan pengelolaan akun shopee dan tokopedia (gambar 3). Hal ini bertujuan untuk memperluas pemasaran produk Tempe Go ke berbagai segmentasi masyarakat. Penggunaan akun shopee ataupun tokopedia tidak memungut biaya, atau dapat diakses secara gratis, sehingga hal ini tidak memberatkan kepada pelaku usaha yang masih tergolong kecil khususnya pengusaha Tempe Go.

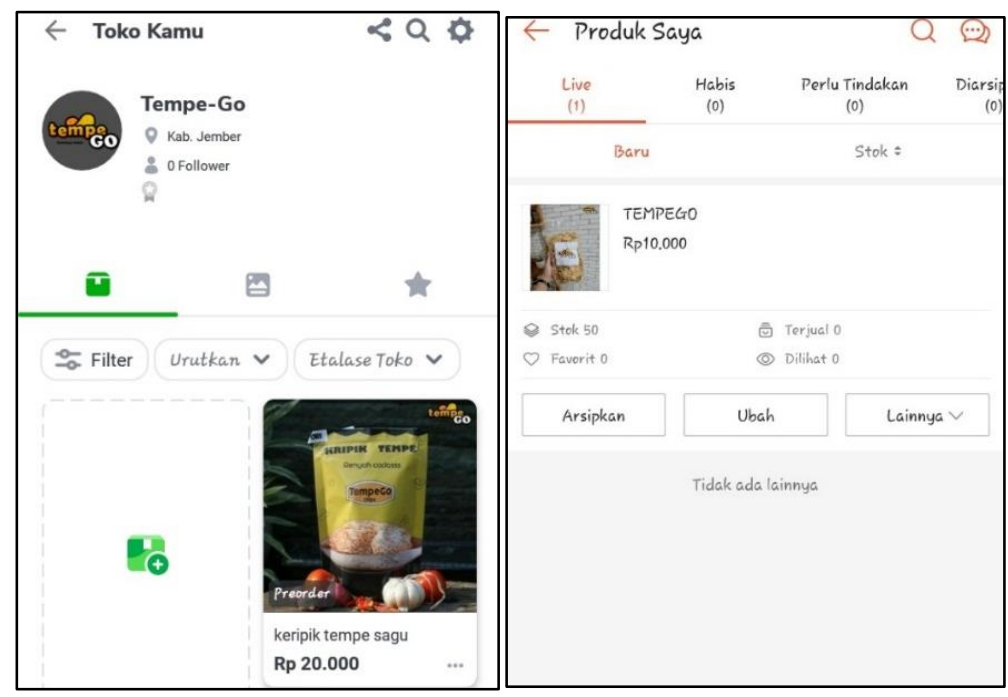

Gambar 3. Pemasaran dengan Akun Tokopedia dan Shopee 
Pemanfaatan media sosial dalam melakukan proses pemasaran produk sangat diperlukan, terutama di era perkembangan teknologi yang semakin meluas. Selain akun shopee dan tokopedia, hal ini tercermin dengan pemanfaatan akun instagram dan whatssapp sebagai sarana perdagangan (gambar 4). Menurut Batin et al. (2020), media sosial merupakan sebuah cara yang paling murah dan mudah dalam melakukan kegiatan-kegiatan promosi suatu produk. Adanya digitalisasi pemasaran sangat menunjang perkembangan sebuah usaha, khususnya pengusaha Tempe Go dalam memasarkan produk. Tercatat bahwa sebelum dilakukan program KKN BTV, penjualan keripik tempe hanya 25 bungkus perminggunya, namun setelah program KKN BTV berlangsung meningkat menjadi 50 bungkus perminggunya. Hal ini muncul dengan adanya beberapa pesanan muncul dari media sosial yang telah dibuat, namun hal ini masih dominan pada penggunaan whatsapp dan instagram. Kedua media mempunyai peran penting dalam menunjang pemasaran produk Tempe Go. Di samping membuat dan mengelola akunakun media sosial, mahasiswa KKN BTV juga membantu pelaku usaha keripik tempe dalam membuat promosi produk.

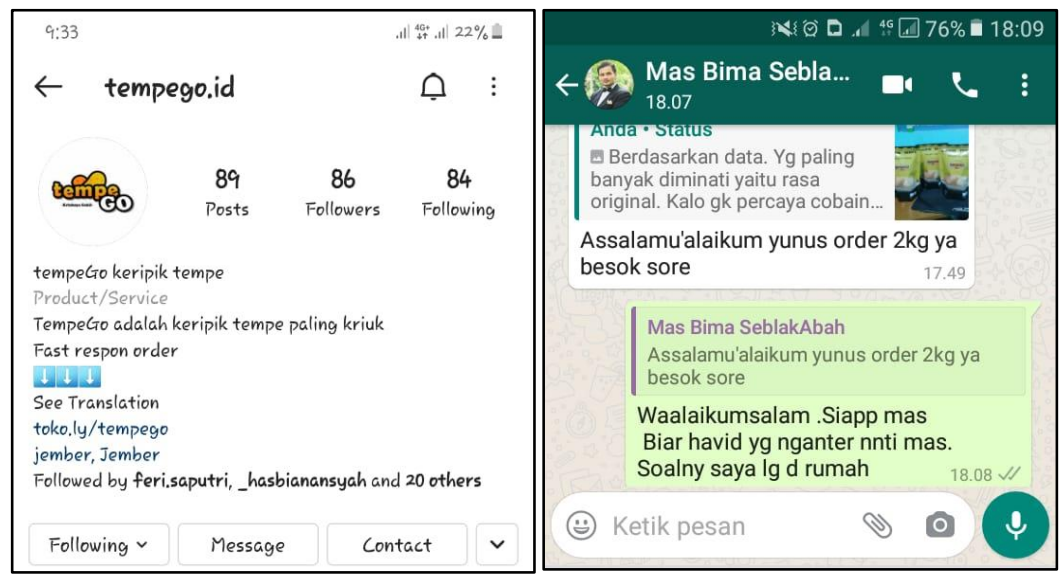

Gambar 4. Akun Instagram \& Whatsapp Tempe Go

\section{Promosi Produk}

Gambar 5 menunjukkan kegiatan promosi yang dilakukan dengan mamanfaatkan media sosial. Promosi dengan menggunakan media sosial cukup dengan upload produk tersebut, tata cara pemesanan, komposisi dan harga jualnya. Cara ini merupakan cara yang paling mudah dan murah dalam melakukan promosi tanpa mengeluarkan biaya untuk keperluan periklanan secara konvensional. Hal ini pasti akan mengurangi cost penjualan yang diperlukan, sehingga dapat menekan biaya produksi yang dibtuhkan. Di samping promosi dengan cara di atas, juga dapat dilakukan promosi dengan memanfaatkan selebgram lokal yang mempromosikan produk tersebut ataupun pejabat-pejabat pemerintahan, misal bupati, gubernur bahkan presiden (Aryansah et al., 2020). Hal ini merupakan upaya-upaya yang dilakukan dalam meningkatkan pemasaran produk Tempe Go kepada masyarakat. 


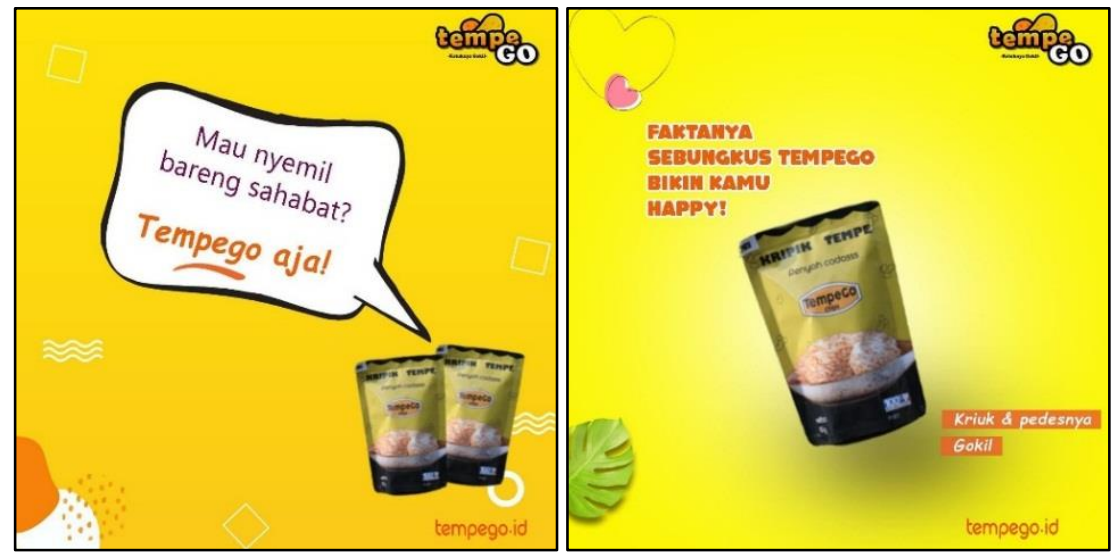

Gambar 5. Iklan Tempe Go

\section{Evaluasi Kegiatan}

Setiap kegiatan yang telah direncanakan selama KKN-BTV telah dilaksanakan secara keseluruhan dan semaksimal mungkin. Kegiatan KKN-BTV ini telah memberikan berbagai ilmu dan pengetahuan bagi sasaran secara sempit dan masyarakat secara luas. Di samping itu, kegiatan KKN-BTV memberikan banyak manfaat bagi mahasiswa yang mengikuti, mulai dari ilmu hingga pengalalaman-pengalaman baru. Beberapa kelas KKN-BTV (gambar 6) telah dilakukan sebagai penunjang kognisi sasaran (masyarakat) yang mengikuti. Adapun kelas KKNBTV yang pernah dilakukan yaitu kelas KKN-BTV pertama dengan judul Pembuatan Market Place dalam Meningkatkan Pemasaran, Kelas KKN-BTV kedua dengan judul Pengenalan dan Pelatihan Design Editing dalam Promosi Produk Pangan, Kelas KKN ketiga dengan judul Pengenalan dan Pelatihan Digital Marketing dalam Pemasaran Produk dan kelas KKN-BTV keempat dengan judul Pentingnya Penerapan Protokol Kesehatan dan Sanitasi Kerja dalam Proses Produksi.

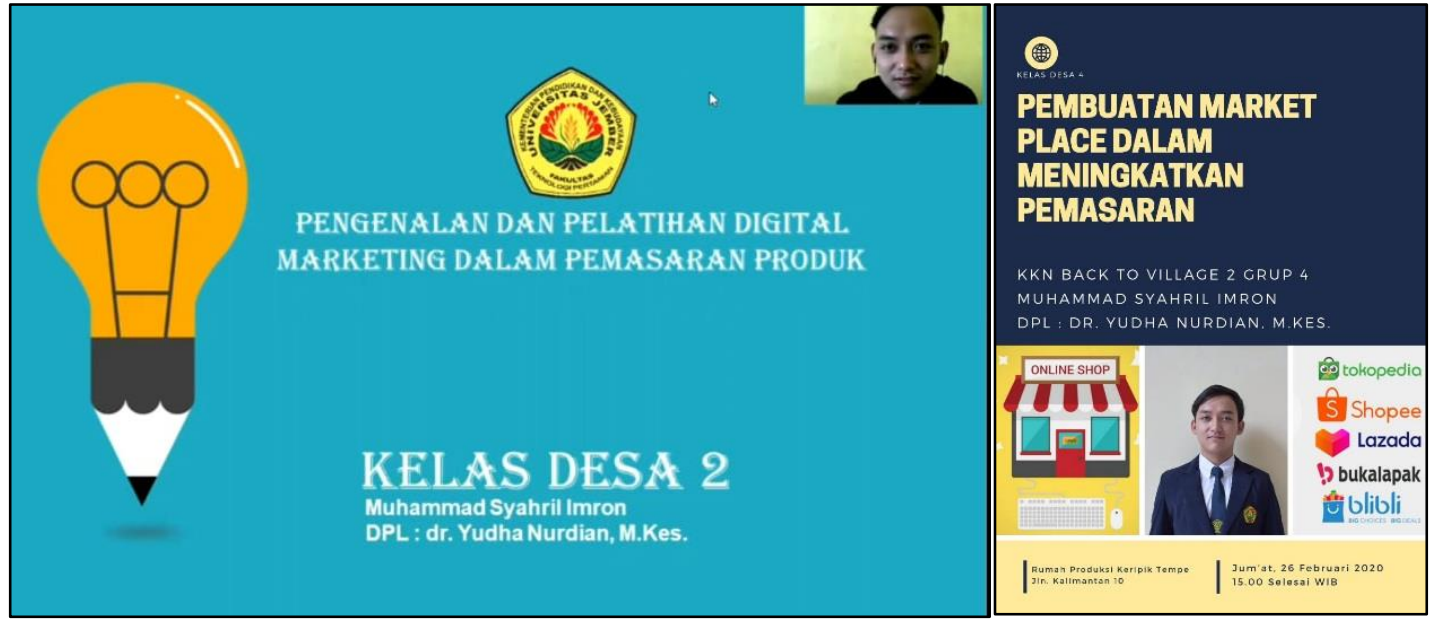

Gambar 6. Kelas KKN-BTV

Kegiatan KKN-BTV selama 45 hari telah berhasil membuat dan mengelola akun media sosial Tempe Go, mulai dari akun instagram, whatsapp, shopee dan tokopedia. Akun media sosial ini menjadi langkah awal dalam mewujudkan digitalisasi pemasaran di UMKM keripik tempe di kelurahan Sumbersari. Hal ini harus terus dijalankan karena zaman terus berkembang dan teknologi semakin canggih. Adanya sebuah teknologi bertujuan untuk mempermudah 
manusia, bukan justru menggeser dan menggantikan posisi manusia di berbagai sektor kehidupan. Pihak pelaku usaha Tempe Go harus tetap dapat mengelola dan menjalankan media sosial yang telah ada, sehingga usaha ini tetap dapat bertahan di era pandemi (Utami dan Azmuri, 2017).

\section{Kesimpulan}

Pengabdian masyarakat yang dikemas dalam bentuk KKN-BTV telah melakukan berbagai bentuk pendambingan dan pelatihan kepada pelaku usaha keripik tempe di kelurahan Sumbersari. Kegiatan yang telah dilakukan tersebut menjadi upaya untuk mewujudkan digitalisasi pemasaran Tempe Go termanifestasikan dengan terbentuknya akun instagram "TEMPE GO"; whatsapp (official account TEMPE GO: 085784803421); tokopedia "TEMPE GO"; dan shopee "TEMPE GO". Akun media sosial ini menjadi gerbang utama terjadinya transaksi secara online atau daring yang dilakukan pihak pengusaha Tempe Go dengan konsumen. Hal ini menunjang peningkatan penjualan pada pelaku usaha keripik tempe, yang awalnya penjualan keripik tempe hanya 25 bungkus perminggunya, namun setelah program KKN BTV berlangsung meningkat menjadi 50 bungkus perminggunya. Berbagai wujud kegiatan yang telah dilakukan dan akun media sosial yang telah terbentuk diharapkan untuk senantiasa diterapkan dan dikelola secara baik, sehingga usaha Tempe Go senantiasa berkembang hingga dapat menembus pasar-pasar nasional maupun internasional. Hal ini juga mendorong pemerintah dan stakeholder lainnya untuk senantiasa membantu pengembangan UMKM masyarakat ke arah digital.

\section{Referensi}

Aminy, A., \& Kartika, F. (2020). Analisis Dampak Covid-19 Bagi UMKM di Jawa Timur. Sidoarjo: Seminar Nasional Official Statistic 2020.

Aryansah, J. E., Mirani, D., \& Martina. (2020). Strategi Bertahan Usaha Mikro Kecil dan Menengah Sektor Kuliner di Masa Pandemi Covid-19. Seminar Nasional AVoER XII, p., 323-329.

Batin, M. H., Ulfa, M., Putra, R. T., Marindah, M., \& Sari, N. (2020). Sosialisasi Bidai (Tirai) Melalui Internet dan Digital Marketing Dalam Upaya Meningkatkan Ekonomi Masyarakat Desa Rantau Durian 1 Kecamatan Lempuing Jaya Kabupaten Ogan Komering Ilir (OKI). Martabe Jurnal Pengabdian Kepada Masyarakat, 3(1): 132-138.

Boyd, W. H. (2020). Manajemen Pemasaran. Jakarta: Erlangga.

Emiliasari, R. N., \& Kosmajadi, E. (2020). Pendampingan Penerapan Manajemen Pemasaran Produk Home Industri Desa Cikadu. Jurnal Pengabdian Masyarakat, 1(2), 106-115.

Ibrahim, Y. B., \& Nurdian, Y. (2020). Pendampingan Pemasaran Produk Unggulan Anyaman Bambu Antirogo di Tengah Pandemi. Jurnal Pengabdian Kepada Masyarakat, 4(2): 303-311.

Kottler, P., \& Keller, K. L. (2009). Manajemen Pemasaran. Edisi 13 Jilid 1. Jakarta: Erlangga.

Kurniawan, P. (2017). Pemanfaatan Media Sosial Instagram Sebagai Komunikasi Pemasaran Modern Pada Batik Burneh. Jurnal Kompetensi, 11(2), 217-225.

Kusumawardhani, R., Ignatius, S. K., Alfiatul, M., \& Agus, D. C. (2020). Pelatihan UKM Rumahan Industri Pangan sebagai Upaya Meminimalkan Kendala Berwirausaha. Jurnal Pengabdian kepada Masyarakat, 6(1), 23-28.

Nugraha, A. S. (2011). Strategi pemasaran keripik tempe pada industri rumah tangga di kecamatan baturetno kabupaten wonogiri. Skripsi, Surakarta: Universitas Sebelas Maret.

Pakpahan, A. (2020). Covid-19 dan Implikasi Bagi Usaha Mikro, Kecil dan Menengah. Jurnal IImiah Hubungan Internasional, 59-64. 
Transformasi: Jurnal Pengabdian Masyarakat, Vol. 17, No. 1, Juni 2021: 65-76

Prayogo, F., \& Nurdian, Y. (2020). Resureksi Bawang Goreng Produk Unggulan Sumberdadap Tulungagung di Tengah Pandemi. Jurnal Ilmiah Pangabdhi, 6(2): 145-148.

Purnamasari, N. E., \& Nurdian, Y. (2020). Pendampingan dan Inovasi Produksi Minuman Herbal Penjaga Imunitas Khas Ngawi Jawa Timur. Jurnal Pengabdian Kepada Masyarakat, 3(4): 19-25. Sarwono, P. (2008). Ilmu Kebidanan. Jakarta: PT. Bina Pustaka.

Utami, G. S., \& Azmuri, W. A. (2017). Iptek bagi Masyarakat Home Industri Keripik Bayam. JPP IPTEK, 1(1), 7-11.

Wahyuni, R. E., \& Nurdian, Y. (2020). Pemberdayaan Usaha Mikro Minuman Jamu Beras Kencur Melalui Pasar Digital di Ranuklindungan, Pasuruan. Jurnal Pengabdian Kepada Masyarakat, 4(2): 19-24. 